\title{
Maurizio Carta, Barbara Lino e Daniele Ronsinvalle (Eds.) RE_CYCLE URBANISM. Visioni, paradigmi e progetti per la metamorfosi circolare
}

LISt Lab, Trento, 2016

Il libro prende le mosse dall'amara constatazione degli effetti prodotti dal pervasivo ed erosivo antroposviluppo, per introdurre un nuovo paradigma urbanistico basato sulla rinnovata alleanza tra componenti umane e naturali guidata dal progetto etico e da una efficace quanto concreta concezione dello sviluppo sostenibile. La svolta prende le mosse dalla crisi economica e finanziaria dei primi anni del nuovo millennio alla quale gli autori attribuiscono il disvelamento dell'inganno della crescita infinita e la nascita di un'urbanistica al contempo visionaria e militante dello sviluppo sostenibile. A distanza di qualche anno dalla data di prima pubblicazione del libro possiamo di certo affermare che tale proposta abbia anticipato il vero cambiamento che oggi stiamo vivendo. La crisi pandemica, infatti, non solo ha messo definitivamente a nudo, semmai ce ne fosse stato bisogno, la pericolosità di un modello di sviluppo autodistruttivo, ma ci ha anche fatto toccare con mano la possibilità di cambiare rotta. La sfida descritta nel libro nasce dalla convinzione che sia possibile vivere un buon antropocene progettando opportunamente il processo di transizione ecologica a partire dalla riattivazione della tradizionale alleanza tra componenti umane e naturali. Una rinascita che non riguarda, quindi, la sola fisicità del nostro ambiente di vita, ma anche e soprattutto la valorizzazione dei flussi e delle energie vitali in esso presenti. Decenni di indiscriminato sfruttamento delle risorse, si legge nel libro, ci hanno

The book begins with a bitter observation of the effects produced by pervasive and erosive human development, then introduces a new urban paradigm based on a renewed alliance between human and natural components guided by ethical planning and by an effective and practical concept of sustainable development. The change takes its cue from the economic and financial crisis of the first years of the new millennium to which the authors attribute the revelation of the deception of infinite growth and the birth of a sustainable urbanism which is both visionary and militant. Some years after the book was first published, we can certainly affirm that this proposal anticipated the real change that we are living today. Indeed, the pandemic has not only clearly revealed, as though there were really any need, the danger of a self-destructive development model, but has also allowed us to reach out and touch the possibility of changing course.

The challenge described in the book is born of the conviction that it is possible to live a good Anthropocene, with a carefully planned process of ecological transition, beginning with the reactivation of the traditional alliance between humankind and nature. A rebirth, therefore, which not only considers the physical environment in which we live, but also and above all, the enhancement of the flows and vital energies present within it. Decades of indiscriminate exploitation of resources, the book affirms, have led us to recognise the right path towards defining a new life cycle characterised by principles of sustainability, beyond the trivialising "reuse consisting only of recycling". A new life cycle which, some time ago, Francesco Rizzo (2009) portato a comprendere la giusta strada per definire un nuovo ciclo di vita improntato ai principi della sostenibilità, al di la della banalizzazione di un "riuso fatto solo di riciclo". Un nuovo ciclo di vita che, qualche tempo prima Francesco Rizzo (2009) faceva corrispondere ad un passaggio esistenziale ed epistemologico verso una società a bassa entropia caratterizzata dal prevalere dei valori qualitativi e spirituali su quelli puramente quantitativi e ad alta intensità di energia. Gli autori del libro interpretano questo passaggio come l'invenzione di sistemi energetici a bassa entropia in quanto fondati sullo sviluppo culturale. Sistemi in grado non solo di ridurre i consumi energetici, ma anche e soprattutto di utilizzare al meglio il lavoro che l'energia può liberare.

Il futuro del neoantropocene descritto nel libro parte dalle città, per espandersi a livello globale in una rinnovata ecologia integrale basata sui processi reciclici di un nuovo metabolismo urbano. Un modello che prende le forme di intriganti quanto promettenti metamorfosi circolari in grado di riattivare i cicli vitali urbani e innescare un rinnovamento profondo della società, tra approcci incrementali ed adattivi e nuovi modelli operativi di progetto, quali patti di riciclo, corresponsabilità progettuale, responsabilità sociale, città aumentata. Immergendosi nel racconto del libro, che di capitolo in capitolo si fa sempre più incisivo e concreto, si ha la netta sensazione della grande distanza che separa il nuovo paradigma urbanistico basato sulla rendita sociale e culturale da quello costruito sulla rendita fondiaria e finanziaria.

Recyclical - non solo recycling - urbanism e City-forming sono i due termini usati per qualificare la proposta e illustrarne i principi applicativi. Il primo, declinato in "sette rami paradigmatici", definisce il modo in cui le azioni possono intercettare i bisogni compared to an existential and epistemological journey towards a society founded on cultural development with low entropy. Systems capable of not only reducing energy consumption, but also and most importantly, of making the best use of the work which the energy can release.

The future of the neo-Anthropocene described in the book begins with the city and expands to a global level of renewed integral ecology based on the recycling processes of a new urban metabolism. A model which takes the form of intriguing and promising circular metamorphoses capable of reactivating urban life cycles and triggering a profound renewal of society, using incremental and adaptable approaches and new operative design models, such as recycling pacts, co-managed design, social responsibility, an augmented city. Immersing oneself in the book, which chapter after chapter becomes more incisive and substantive, produces a distinct awareness of the great distance which separates the new urban paradigm based on social and cultural profit from that built on land revenues and finance.

Recyclical - not only recycling - urbanism and City-forming are two terms used to categorise the proposal and illustrate the principles of application. The first, composed of "seven paradigmatic branches", defines the way in which the actions can intercept the needs of the physical and vital components of the territory, while the second, more evocative term, defines the operational protocol, or rather the programme of actions which are formed in an adaptable way based on the consolidation of the roles and values. A programme of colonizing actions, as described in the text, which react 
delle componenti fisiche e vitali del territorio, mentre il secondo, più evocativo, ne definisce il protocollo operativo, ovvero il programma di azioni che si vanno a formare in modo adattivo in base al consolidamento dei ruoli e dei valori. Un programma di azioni colonizzatrici, comè scritto nel testo, che agiscono come catalizzatori delle risorse identitarie, lavorando sui palinsesti piuttosto che sulla sovrascrittura omologante. In questo senso il city-forming, in quanto prodotto/processo, si pone esso stesso come strumento resiliente in grado di adattare la propria efficacia al rapporto osmotico che è in grado di costruire con gli abitanti. Una bella evoluzione di ciò che Dioguardi (2009) definì "città laboratorio", ovvero un insieme di terminali intelligenti e rete di innovazioni non soltanto tecnologiche, ma anche e soprattutto di natura sociale attraverso le quali plasmare l'esistente. Consapevoli di essere gli artefici dell'agenda progettuale della metamorfosi circolare, gli autori arricchiscono i concetti base con attributi non propriamente disciplinari, quasi a voler sottolineare la dimensione ipercomplessa della sfida che si pone e che viene descritta come la riscrittura del codice genetico dei nostri spazi di vita per produrre nuova intelligenza urbana. In questa visione la città assume le sembianze di un super organismo costituito da insiemi di individui che si muovono all'unisono in quanto guidati da una visione anticipatrice e motivante. Questa seconda immagine usata dagli autori chiarisce molto bene il principio di interdipendenza tra la dimensione fisica e inanimata degli spazi e quella viva e pulsante delle persone. Un principio di congiunzione e interdipendenza che potremmo definire di space/feeling/action per il quale la città, alla stregua di un organismo vivente, risulta in grado di auto-analizzarsi di continuo attraverso la rappresentazione e la condivisione sociale degli elementi di trasformazione, nonché di

as catalysts for resources of identity, working on palimpsests rather than homologous overwriting. In this sense, cityforming, as a product/process, proposes itself as a resilient instrument able to adapt its own efficacy to the osmotic relationship which it is able to form with the inhabitants. A beautiful evolution which Dioguardi (2009) defines as the "city laboratory", namely a mixture of intelligent terminals and networks of innovation which are also and first and foremost of a social nature through which the existing may be moulded.

Conscious of being the creators of the design agenda for circular metamorphosis, the authors enrich the basic concepts with not entirely disciplined features, almost as if they want to highlight the hyper-complexity of the challenge which is presented and which is described as the rewriting of progettare in modo consapevole soluzioni adattive attivando l'intelligenza collettiva. Gli autori del libro parlano a questo proposito di "processo-progetto entro uno scenario previsto", il che chiarisce ancora meglio la natura non più chiusa e predefinita, ma open source del contributo pianificatorio e progettuale che si costruisce nel tempo catalizzando e capitalizzando l'esperienza.

Il volume è la raccolta delle premesse e degli esiti del Workshop PMO/Re-verse Hyper-cycling "Costa Sud" svoltosi a Palermo nel settembre 2014 e in quanto tale è un concentrato sapientemente miscelato di teoria e pratica. Il workshop è stato infatti una iniziativa di progettazione urbanistica ma anche di politica urbana e di innovazione sociale prodotta nell'ambito del PRIN "Re-cycle Italy". Coordinato da Renato Bocchi, e promossa dall'UdR di Palermo insieme al Comune di Palermo, l'ANCE Palermo e l'Ordine degli Architetti, Pianificatori, Paesaggisti, Conservatori della Provincia di Palermo, il workshop ha prodotto concrete iniziative capaci di intervenire sia sugli stili di vita, sia sui modi d'uso del territorio e sulle forme di comunità, con l'obiettivo dichiarato di riportare i temi dello sviluppo al centro delle iniziative per il nostro mezzogiorno. Consultando alcune dinamiche territoriali post pandemia verrebbe da dire che gli autori abbiano ancora una volta anticipato il cambiamento.

Daniele Fanzini

\section{REFERENCES}

Dioguardi, G. (2009), Organizzazione, cultura, territorio, Franco Angeli, Milano, Italia.

Rizzo, F. (1989), Economia del patrimonio architettonico ambientale, Franco Angeli, Milano, Italia. the genetic code of the spaces in which we live in order to produce a new urban intelligence. Within this vision, the city assumes the semblance of a super organism made up of a mixture of individuals who move in unison, guided by an anticipatory and motivational vision. This second image used by the authors really clarifies the principle of interdependency between the physical inanimate dimension of the spaces and the live pulsating human dimension. A principle of conjunction and interdependency which we can define as space/feeling/action, the same as a living organism which is able to continuously self-analyse through social representation and sharing of the transformative elements, as well as being able to design conscious adaptable solutions activating the collective intelligence. The authors of the book describe this as "process-design within a planned scenario", which provides an even clearer picture of nature no longer confined and predefined, but an open source in the planning and design process which is built over time catalysing and capitalising the experience.

The volume is a collection of the prerequisites and results of the $\mathrm{PMO} /$ Re-verse Hyper-cycling "Costa Sud" Workshop held in Palermo in September 2014 and as such is a skilfully mixed concentrate of theory and practice. Indeed, the Workshop was an urban planning initiative which included urban policy and social innovation produced as part of PRIN "Re-cycle Italy". Coordinated by Renato Bocchi and promoted by the UdR of Palermo together with the Municipality of Palermo, ANCE Palermo and the Order of Architects, Planners, Landscapers, Preservationists of the Province of Palermo, the workshop produced practical initiatives able to impact on the lifestyle, use of the territory and forms of community with the declared aim of bringing the issues of development back to the centre of the initiatives for our southern regions. With regards certain post-pandemic territorial dynamics, it may be said that the authors have once again anticipated the change.

Daniele Fanzini 